\title{
Environmental influence on coprophagous Scarabaeidae (Insecta, Coleoptera) assemblages in the Pantanal of Mato Grosso
}

\author{
A. S. O. Tissiani ${ }^{a, b *}$, W. O. Sousa ${ }^{a, c}$, G. B. Santos ${ }^{a, c}$, S. Ide ${ }^{d}$, L. Battirola $^{a, e}$ and M. I. Marques ${ }^{a, b}$ \\ ${ }^{a}$ Universidade Federal de Mato Grosso - UFMT, Av. Fernando Corrêa da Costa, 2367, \\ Bairro Boa Esperança, CEP 78060-900, Cuiabá, MT, Brazil

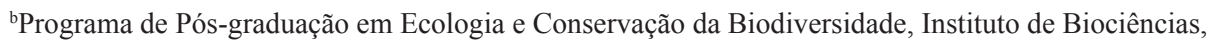 \\ Universidade Federal de Mato Grosso - UFMT, Av. Fernando Correa da Costa, 2367, \\ Boa Esperança, CEP 78060-900, Cuiabá, MT, Brazil \\ 'Instituto de Ciências Biológicas e da Saúde, Universidade Federal de Mato Grosso - UFMT, \\ Campus Universitário do Araguaia, CEP 78000-600, Barra do Garças, MT, Brazil \\ ${ }^{\mathrm{d} C e n t r o ~ d e ~ P e s q u i s a ~ e ~ D e s e n v o l v i m e n t o ~ d e ~ S a n i d a d e ~ V e g e t a l ~-~ C P D S V, ~ I n s t i t u t o ~ B i o l o ́ g i c o, ~}$ \\ Av. Conselheiro Rodrigues Alves, 1252, Vila Mariana, CEP 04014-002, São Paulo, SP, Brazil \\ 'Instituto de Ciências Naturais, Humanas e Sociais, Universidade Federal de Mato Grosso - UFMT, \\ Campus Universitário de Sinop, Av. Alexandre Ferronato, 120, Setor Industrial, CEP 78557-267, Sinop, MT, Brazil \\ *e-mail: atissiani@gmail.com
}

Received: May 2, 2014 - Accepted: July 23, 2014 - Distributed: November 30, 2015

(With 2 figures)

\begin{abstract}
Here we examine assemblage structure of coprophagous Scarabaeidae (dung beetles) in the Pantanal of the state of Mato Grosso with respect to flooding regimes, soil texture, leaf litter volume and tree dominance in native and exotic pastures. Samples were collected along 30 transects of $250 \mathrm{~m}$ in length in a $5 \times 5 \mathrm{~km}$ grid $\left(25 \mathrm{~km}^{2}\right)$. Five pitfalls baited with human feces were placed in each transect. A total of 1692 individuals in 19 species were captured, the majority in the subfamily Scarabaeinae and Aphodiinae. Assemblages were influenced by the duration of flooding and leaf litter volume. None of the other habitat variables was correlated with species richness. Cultivated pastures with exotic grasses were unimportant for composition of the assemblages of beetles. These results indicate that duration of flooding is the most important regulating force in this community.
\end{abstract}

Keywords: humid areas, dung beetle, environmental gradient, periodic flooding, species distribution patterns.

\section{Influência ambiental sobre assembleias de Scarabaeidae coprófagos (Insecta: Coleoptera) no Pantanal de Mato Grosso}

\section{Resumo}

Esse estudo avaliou a estrutura espacial de assembleias de Scarabaeidae coprófagos no Pantanal de Mato Grosso, em função do tempo de inundação, textura do solo, volume da serapilheira, dominância de arbóreas, pastagens nativa e exótica. As coletas foram realizadas em 30 transectos de $250 \mathrm{~m}$ cada distribuídos sistematicamente em uma área de $25 \mathrm{~km}^{2}$. Cinco armadilhas pitfall iscadas com fezes humanas foram instaladas em cada transecto, e obtidos 1.692 indivíduos distribuídos em 19 espécies pertencentes às subfamílias Scarabaeinae e Aphodiinae. A estrutura e composição das assembleias foram afetadas pelo tempo de inundação e o volume da serapilheira. Todas as variáveis explanatórias foram fracamente correlacionadas e de forma não significativa com a riqueza de espécies. A existência de pastagem exótica não afetou a composição das assembleias de besouros. Esses resultados indicam que o tempo de inundação é a principal força reguladora dessa comunidade no ambiente pantaneiro.

Palavras-chave: áreas úmidas, besouros coprófagos, gradiente ambiental, inundação periódica, padrões de distribuição de espécies.

\section{Introduction}

Areas that are subject to periodic flooding are classified with respect to amplitude, frequency, predictability and force of flooding, all of which can be quite variable
(Junk, 1997; Junk et al., 2011). Also, characteristics of the surrounding landscape, including soil types, vegetation and so on, can result in a wide variety of distinct conditions 
(Junk et al., 1989) that in turn favor different assemblages of organisms and, consequently, influence local biodiversity (Cunha and Junk, 2011). The theory of flood pulses establishes relationships between the physical environment and the many interactions between terrestrial and aquatic compartments of the flooded areas, thereby influencing local geomorphology and landscape structure (Junk et al., 1989; Adis and Junk, 2002; Junk and Welcomme, 1990).

Where floods are common, habitats are a gradient between areas above and under water that vary over space and time, with consequences for organisms. Aquatic communities are directly influenced by water levels and the duration of inundations ( $\mathrm{Li}$ and Gelwick, 2005) and once floods abate, the above-water regions are influenced by chemical and textural changes in the soils as a consequence of flooding (Poff et al., 1997; Girard et al., 2010; Nadja, 2013). These dynamics strongly influence the distribution and abundance of terrestrial organisms for extended periods of time after flooding (Girard et al., 2010). Thus, the duration of floods can be considered a measure of soil and plant conditions that are consequences of transport and deposition of sediments during floods rather than local topography (Hamilton et al., 1996, 1997).

Flood dynamics have also influenced plant and animal evolution, with resulting adaptations and strategies for survival during floods, and which may be influenced by flood intensity and frequency (Adis, 1997; Adis et al., 2001).

Assemblages of coprophagous Scarabaeidae (dung beetles) are diverse throughout the tropics. Dung beetles form dung into balls that are then rolled away and buried in galleries beneath the soil surface and on which larvae feed. Conditions for these dung balls will depend on soil texture, humidity and temperature, all of which vary across the landscape (Halffter and Matthews, 1966; Halffter, 1991). The greatest diversity of dung beetles is found in well-preserved environments where communities may have distinct structures and feeding guilds (Halffter, 1991) and which are sensitive to variation in soil conditions (Almeida et al., 2011; Halffter et al., 1992).

Here we examine spatial variation in dung beetle assemblage structure in the Pantanal of the state of Mato Grosso, Brazil. We test how flood duration, soil texture, leaf-litter volume, and native and exotic pasture are associated with community structure. Specifically, we test whether the assemblages are influenced by flood duration, whether species substitution follows a flood duration gradient, and whether soil texture, leaf litter layer and vegetation structure directly influence dung-beetle species richness.

\section{Methods}

\subsection{Study area}

We carried out this study between the Cuiabá, Bento Gomes and Paraguaizinho Rivers, a region called the Poconé Pantanal, at Pirizal ( $16^{\circ} 15^{\prime}$ to $17^{\circ} 54^{\prime}$ S, $56^{\circ} 36^{\prime}$ to $57^{\circ} 56 \mathrm{~W}$ ), in the state of Mato Grosso, Brazil (see Figure 1). Altitude is around $114 \mathrm{~m}$ and annual rainfall averages
$1400 \mathrm{~mm}$ (Cunha and Junk, 2004). The region is a mosaic of gallery forest, forest patches and savannas that are all influenced by the local topography and water regimes (Cunha et al., 2007). Forests are often monodominant in which one species accounts for $>50 \%$ of the canopy (Arieira and Cunha, 2006). The landscape comprises a variety of other formations that are consequences of subtle changes in topographic relief and can include pasture that often has introduced plants (Almeida et al., 2000; Silva et al., 2000).

Sampling was carried out during September and October 2007, when this region was above water level. We established 30 transects of $250 \mathrm{~m}$ in length, separated by about $1 \mathrm{~km}$ in a grid of $5 \times 5 \mathrm{~km}$, following (Magnusson et al., 2005, see Figure 1). Samples were collected using pitfall traps (Adis, 2002) with alcohol in the trap and human feces as bait (Milhomem et al., 2003). Bait was wrapped in gauze and hung at the level of the opening to the pitfall trap. Each transect had five pitfall traps with $50 \mathrm{~m}$ between each traps, where they remained in place for 72 hours. All specimens collected are in the Collection of the Terrestrial Arthropod Ecology and Taxonomy Laboratory at the Bioscience Institute of the Federal University of Mato Grosso, Brazil.

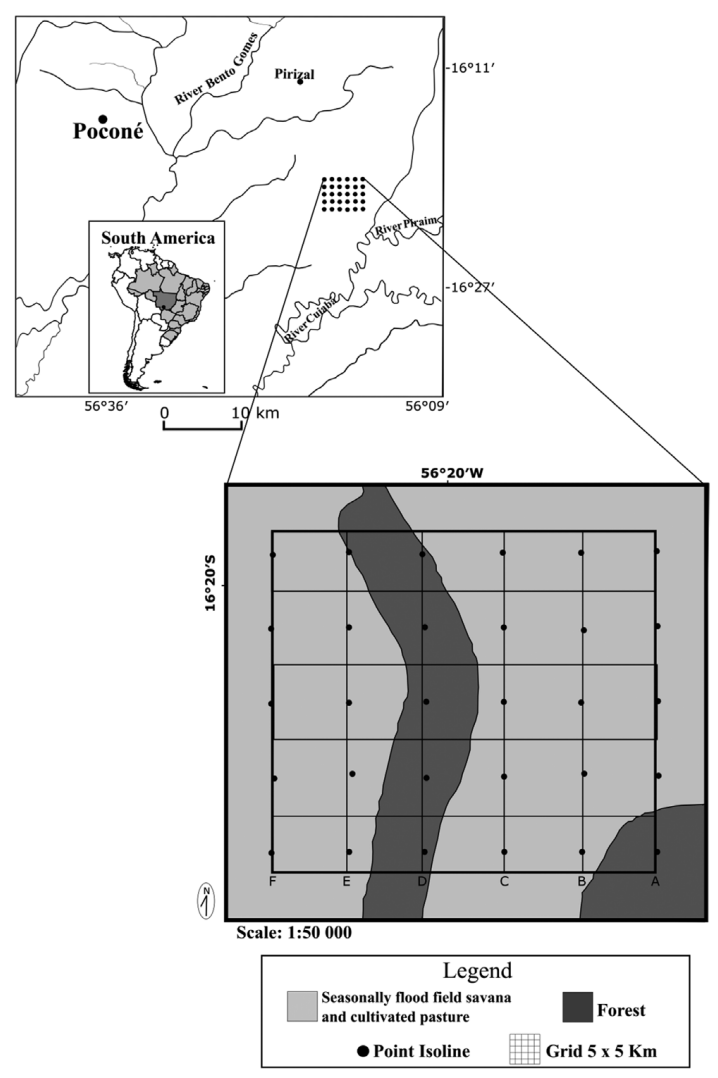

Figure 1. Map of the study area, indicating the $5 \times 5 \mathrm{~km}$ plot, in the northern Pantanal of Mato Grosso. A through $\mathrm{F}$ indicate the trail grid of the plot and circles indicate each sampling point. 


\subsection{The environment}

We measured duration of inundation (days), herbaceous cover, tree dominance, leaf litter volume and soil texture clay $\left(\mathrm{g} \mathrm{kg}^{-1}\right.$ ) following (Magnusson et al., 2005). These data are available at the "Padrões de Biodiversidade em Meso-escala, dos Diferentes Sistemas Pastoris do Pantanal de Mato Grosso (BIOPAN)", of the "Núcleo de Estudos do Pantanal (NEPA) of the Federal University of Mato Grosso" and the Center for Research in the Pantanal (CPP).

\subsection{Data analysis}

To avoid multicolinearity, we examined the correlational structure of the original variables. We describe species composition of the dung-beetle assemblage using non-metric multidimensional scaling (NMDS). Ordination was based on an abundance matrix using the Bray-Curtis index of association. The axes from NMDS that describe community structure were used as dependent variables when testing environmental variables and their influence on community composition through multiple regression analysis (Legendre and Legendre, 1998).

To test environmental effects on species composition, we used partial redundancy analysis (pRDA) using three matrices. The species composition matrix as the dependent variable and the environmental matrix and the distance matrix as the two independent variable matrices. Analyses were carried out in the R package Vegan (R Development Core Team, 2008) and Systat 11 (Wilkinson, 2004).

\section{Results}

A total of 1,692 individuals were collected, comprising 19 species in the subfamilies Scarabaeinae (1,680 individuals, 14 species in 10 genera represented $99 \%$ of the total) and Aphodiinae with 12 individuals, 5 species and one genus, Ataenius (Harold, 1867). The most abundant genus was Trichillum Harold, 1868 (1,175 individuals, 70\% of the total) all of which were Trichillum externepunctatum Preudhomme de Borre, 1886 the most abundant species (see Table 1).

We used as environmental (independent) variables flood duration (days), tree dominance, herbaceous cover and leaf-litter volume (see Table 2). The two NMDS axes explained $83 \%$ of the variation in community composition ( stress $=6.40$ ). Transects did not form well-defined groups based on the independent variables. Flood duration was important for the two NMDS axes to describe the assemblage structure (Pillai trace $=0.270, \mathrm{~F}_{2,24}=4.436$, $\mathrm{P}=0.023)$. Thus, the assemblages had a different species

Table 1. Dung beetles (Insecta, Coleoptera, Scarabaeidae) from the Pantanal of Mato Grosso, collected September-October 2007.

\begin{tabular}{|c|c|c|c|}
\hline Species & $\mathbf{N}$ & Subfam \% & Guild \\
\hline \multicolumn{4}{|l|}{ Aphodiinae } \\
\hline \multicolumn{4}{|l|}{ Eupariini } \\
\hline Ataenius aequalis Harold, 1880 & 1 & 8.3 & $\mathrm{E}$ \\
\hline Ataenius opacipennis Schimidt, 1910 & 1 & 8.3 & $\mathrm{E}$ \\
\hline Ataenius sp. 1 & 2 & 16.7 & $\mathrm{U}$ \\
\hline Ataenius sp. 2 & 6 & 50.0 & $\mathrm{U}$ \\
\hline Ataenius sp. 3 & 2 & 16.7 & $\mathrm{U}$ \\
\hline \multicolumn{4}{|l|}{ Scarabaeinae } \\
\hline \multicolumn{4}{|l|}{ Ateuchini } \\
\hline Ateuchus aff. contractum Balthasar, 1939 & 32 & 1.9 & $\mathrm{P}$ \\
\hline Ateuchus aff. viridimicans Boucomont, 1935 & 61 & 3.6 & $\mathrm{P}$ \\
\hline Besourenga aff. minutus Vaz-de-Mello, 2008 & 8 & 0.5 & $\mathrm{E}$ \\
\hline Canthidium Eucanthidium) sp. & 161 & 9.6 & $\mathrm{U}$ \\
\hline Trichillum externepunctatum Preudhomme de Borre, 1886 & 1,175 & 69.9 & $\mathrm{E}$ \\
\hline Uroxys sp. & 27 & 1.6 & $\mathrm{U}$ \\
\hline \multicolumn{4}{|l|}{ Canthonini } \\
\hline Canthon curvadilatatum Schimidt, 1920 & 6 & 0.4 & $\mathrm{~T}$ \\
\hline Canthon ornatus Redtenbacher, 1867 & 1 & 0.1 & $\mathrm{~T}$ \\
\hline Deltochilum aff. elongatum Felshe, 1970 & 1 & 0.1 & $\mathrm{~T}$ \\
\hline Pseudocanthon aff. xanthurus Blanchard, 1846 & 4 & 0.2 & $\mathrm{~T}$ \\
\hline \multicolumn{4}{|l|}{ Coprini } \\
\hline Dichotomius nisus Olivier, 1789 & 38 & 2.3 & $\mathrm{P}$ \\
\hline Dichotomius opacipennis Luederwaldt, 1931 & 2 & 0.1 & $\mathrm{P}$ \\
\hline Ontherus appendiculatus Mannerheim, 1829 & 151 & 9.0 & $\mathrm{P}$ \\
\hline Ontherus sulcator Fabricius, 1775 & 13 & 0.8 & $\mathrm{P}$ \\
\hline Total & 1,692 & - & - \\
\hline
\end{tabular}

$\mathrm{N}$ is number of individuals collected. Guilds are $\mathrm{E}$ - endocoprid, $\mathrm{T}$ - telecoprid, $\mathrm{P}$ - paracoprid, $\mathrm{U}$ - unknown. 
depending on the flood regime, which was the variable most associated with the assemblage structure in the multivariate regression (Figure 2). Controlling for the effects of location, the remaining environmental variables explained $10 \%$ of the variation $\left(\mathrm{r}^{2}=0.10, \mathrm{p}=0.029\right)$, while space, which represents any unstudied variables that might be spatially clustered, was unimportant $\left(\mathrm{r}^{2}=0.210, \mathrm{p}=0.166\right.$, Table 2$)$.

Species richness was independent of the environmental variables (see Table 3) even though the distribution of species seemed to be associated with the flood gradient. Besourenga aff. minutus Saylor, 1935 was found in transects that were underwater for 30 days, while Atenius opacipennis Schmidt, 1910, A. aequalis Harold, 1980 and Ataenius sp. 3 occurred in transects that were underwater for $>125$ days during the flood season. The remaining species occurred over the entire gradient or concentrated in intermediate regions T. externepunctatum was the only species found in all transects (Figure 2).

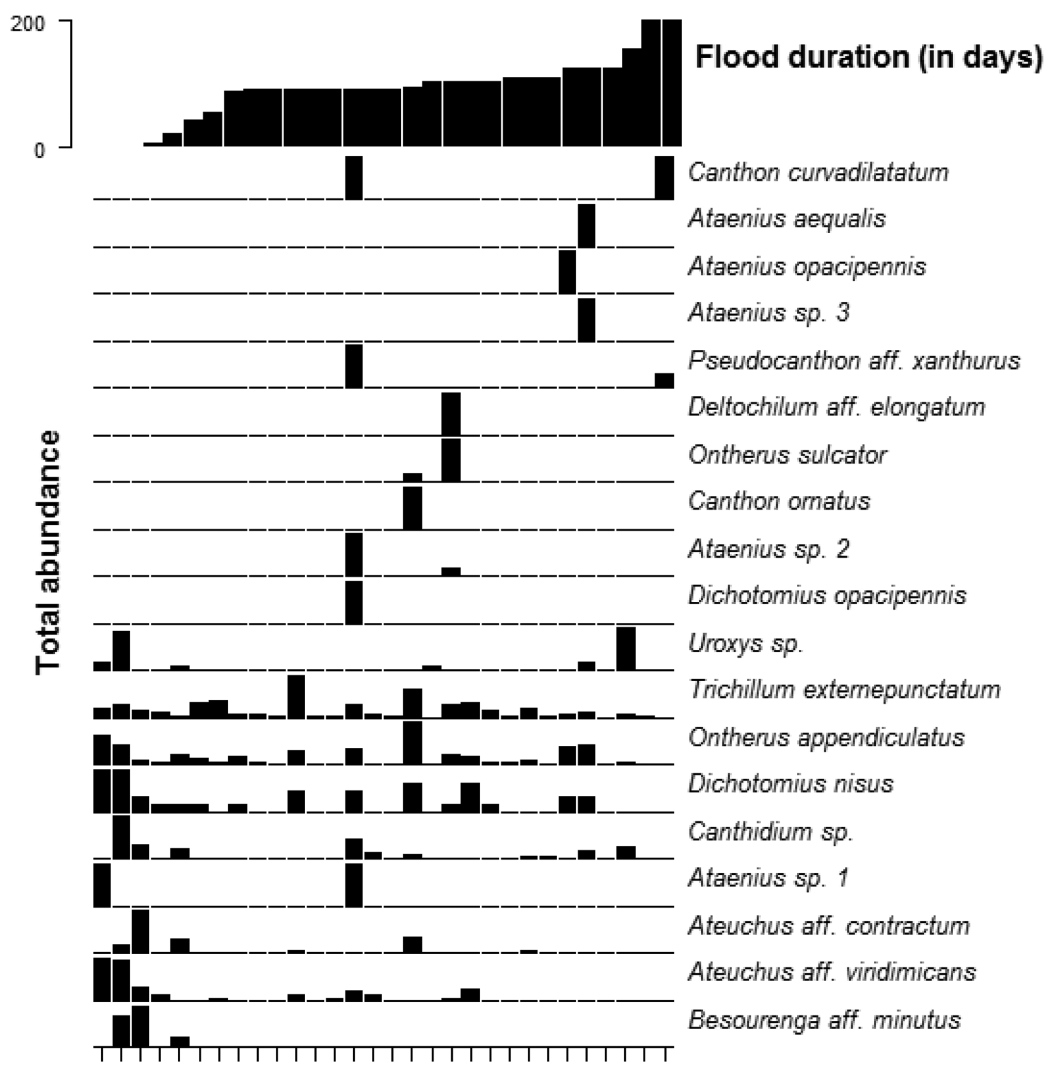

Flood duration (in days)

Figure 2. Ordination of the 19 most common species by abundance (see Table 1 for total abundances) and flood duration in days, collected from September to October 2007 in the Pantanal of Mato Grosso.

Table 2. Correlations among environmental variables collected September-October 2007, in the Pantanal of Mato Grosso.

\begin{tabular}{|c|c|c|c|c|c|c|}
\hline Variable & Flood days & $\begin{array}{c}\text { Tree } \\
\text { dominance }\end{array}$ & $\begin{array}{l}\text { Herbaceous } \\
\text { cover }(\%)\end{array}$ & $\begin{array}{c}\text { Herbaceous } \\
\text { cover }(\%) \\
\text { Native } \\
\end{array}$ & $\begin{array}{c}\text { Herbaceous } \\
\text { cover }(\%) \\
\text { Exotic } \\
\end{array}$ & Leaf Litter \\
\hline Tree dominance & $0.234^{*}$ & & & & & \\
\hline Herbaceous cover $(\%)$ & 0.079 & -0.190 & & & & \\
\hline $\begin{array}{l}\text { Herbaceous cover }(\%) \\
\text { native }\end{array}$ & 0.030 & 0.181 & & & & \\
\hline $\begin{array}{l}\text { Herbaceous cover }(\%) \\
\text { exóticas }\end{array}$ & -0.035 & $-0.564^{*}$ & & & & \\
\hline Leaf Litter & 0.096 & -0.055 & $-0.565^{*}$ & $-0.580 *$ & 0.032 & \\
\hline Argila & $0.770^{*}$ & 0.159 & 0.061 & -0.049 & 0.108 & 0.145 \\
\hline
\end{tabular}

*Bold positive or negative coefficients indicate positive or negative correlation with 1 or -1 being the strongest positive or negative relationship. 
Table 3. Partial redundancy analysis of space (unstudied variables) and tested environment as influences on the dung beetle (Insecta, Coleoptera, Scarabaeidae) assemblage in the Pantanal of Mato Grosso, collected September-October 2007.

\begin{tabular}{lcll}
\hline \multicolumn{1}{c}{ Variable } & Abundance & $\mathbf{R}^{2}$ & P \\
\hline Residual & 0.90 & & \\
Space & 0.02 & 0.210 & 0.166 \\
Environment & 0.10 & $0.018^{*}$ & $0.029^{*}$ \\
\hline
\end{tabular}

*Values are significant at the $5 \%$ probability (ANOVA).

\section{Discussion}

Dung beetles in the Pantanal are apparently generalists and all species can be found over wide gradients of environmental conditions. Redundancy analysis suggests that $90 \%$ of the distribution of dung beetles is unexplained by the variables selected here, and which we predicted a priori would be most important. While surprising, we speculate that perhaps the variables we measured were incomplete, or indeed, dung beetles accept a wide variety of conditions. Indeed, the meso spatial scale should have been large enough to find distribution patterns if they did exist (e. g. Braga-Neto et al., 2008).

Soil texture, especially clay, is often a very important factor in determining the time interval during which soils remained water-saturated (Tsubo et al., 2005). The strongest correlation among our environmental variables illustrates the relationship between flood duration and soil texture $(\mathrm{r}=0.77, \mathrm{P}<0.05)$. Soil texture and flood interval are regulators of assemblage structure in dung beetles of humid regions. Two important factors might explain this result. First, most species in this study are paracoprid and telecoprid. These groups tend to bury feces and they prefer soils that are a combination of sand and clay, which are more easily excavated but remain firm when tunnels are dug (Halffter and Matthews, 1966). Sandy soils are also more rapidly drained after rain (e.g. Tsubo et al., 2007) and consequently are rapidly colonized by grasses (Heckman, 1998), which, in turn, attract large herbivores whose feces are food for the dung beetles.

The weaker correlations between exotic pasture and tree dominance $($ rho $=-0.564)$, total herbaceous cover and leaf litter (rho $=-0.565)$, and native herbaceous cover and leaf-litter volume $($ rho $=-0.580)$ are probably attributable to clearing pastures by cutting trees that is done periodically in the Pantanal (Heckman, 1998; Junk and Cunha, 2005).

Other studies in a variety of environmental settings have found important relationships between environment (including soils, humidity and others), resources, vegetation and diversity in dung-beetles (Halffter and Matthews, 1966; Navarrete and Halffter, 2008). However, here, time under water was the single most important variable in spatial variation in dung-beetle abundance. This supports the ideas of the importance of periodic flooding and its influence on habitats in flooded areas (Junk et al., 1989, 2011; Pott et al., 1996; Junk, 1997). Seasonal problems of water stress, common to the Pantanal, may favor the establishment or dominance of generalist species throughout the habitat gradient (see Figure 2) and which respond best to periodic disturbances (e. g. Junk et al., 2006; Feener Junior et al., 2008).

Relationships between species richness and ecosystem functions may be variable, negative or non-existent (Schwartz et al., 2000). The function of the soil may not be correlated with species richness due to the few species being studied and functional redundancy due to the trophic plasticity of some species of edaphic fauna (Setälä et al., 2005). Thus, we suggest that, because this fauna was dominated by one common species, its generalist nature and functional redundancy of space and resource use led to the lack of correlations among the variables we chose.

The dung beetle community is structured as a consequence of flooding and species substitution along a gradient. Thus, species richness and composition of any local area is not directly structured by soil texture and other environmental variables.

\section{Acknowledgements}

We thank the Padrões de Biodiversidade em Meso-escala dos Diferentes Sistemas Pastoris do Pantanal de Mato Grosso (BIOPAN), Núcleo de Estudos do Pantanal (NEPA), Centro de Pesquisas do Pantanal (CPP) and the Conselho Nacional de Desenvolvimento Científico e Tecnológico (CNPq) all for their financial support. We thank Lúcia Matheus for her help with statistical analysis and Francisco de A. Rondon for help in the field. To the memory of Joachim U. Adis of the Max Planck Institute of Limnology, we are forever grateful for his contribution teaching us about the arthropods of the Pantanal and central Amazon.

\section{References}

ADIS, J., 1997. Terrestrial invertebrates: survival strategies, group spectrum, dominance and activity patterns. In: W.J. JUNK, ed. The Central Amazon floodplain. Berlin: Springer, pp. 299-317. Ecological Studies.

ADIS, J., 2002. Recommended sampling techniques. In: J. ADIS, ed. Amazonian Arachnida and Myriapoda: identification keys to all classes, orders, families, some genera, and lists of known terrestrial species. Sofia-Moscow: Pensoft, pp. 555-576.

ADIS, J. and JUNK, W.J., 2002. Terrestrial invertebrates inhabiting lowland river floodplains of Central Amazonia and Central Europe: a review. Freshwater Biology, vol. 47, no. 4, pp. 711-731. http:// dx.doi.org/10.1046/j.1365-2427.2002.00892.x.

ADIS, J., MARQUES, M.I. and WANTZEN, K.M., 2001. First observations on the survival strategies of terricolous arthropods 
in the northern Pantanal wetland of Brazil. Andrias, vol. 15, pp. 127-128.

ALMEIDA, N., SILVEIRA, E. A. and BARROS, L.T.L.B., 2000. Mapa da vegetação e uso do solo da região de Poconé, MT: I descrição das unidades. In: III Simpósio sobre Recursos Naturais e Sócios Econômicos do Pantanal: os desafios do Novo Milênio, 2000, Corumbá, MS. Brasília: Embrapa.

ALMEIDA, S., LOUZADA, J., SPERBER, C. and BARLOW, J., 2011. Subtle land-use change and tropical biodiversity: dung beetle communities in Cerrado grasslands and exotic pastures. Biotropica, vol. 43, no. 6, pp. 704-710. http://dx.doi.org/10.1111/ j.1744-7429.2011.00751.x.

ARIEIRA, J. and CUNHA, C.N., 2006. Fitossociologia de uma floresta inundável monodominante de Vochysia divergens Pohl (Vochysiaceae), no Pantanal Norte, MT, Brasil. Acta Botanica Brasílica, vol. 20, no. 3, pp. 569-580. http://dx.doi.org/10.1590/ S0102-33062006000300007.

BRAGA-NETO, R., LUIZÃO, R.C.C., MAGNUSSON, W.E., ZUQUIM, G. and CASTILHO, C.V., 2008. Leaf litter fungi in a Central Amazonian Forest: the influence of rainfall, soil and topography on the distribution of fruiting bodies. Biodiversity and Conservation, vol. 17, no. 11, pp. 2701-2712. http://dx.doi. org/10.1007/s10531-007-9247-6.

CUNHA, C. and JUNK, W.J., 2011. Landscape units of the Pantanal: structure, function and human use. In: W.J. JUNK, C.J. SILVA, C.N. CUNHA and K.M. WANTZEN, eds. The Pantanal: ecology, biodiversity and sustainable management of a large neotropical seasonal wetland. Sofia-Moscow: Pensoft, pp. 299-324.

CUNHA, C.N., JUNK, W.J. and LEITÃO, H.F., 2007. Woody vegetation in the Pantanal of Mato Grosso, Brazil: a preliminary typology. Amazoniana, vol. 19, no. 3-4, pp. 159-184.

CUNHA, C.N. and JUNK, W.J., 2004. Year-to-year changes in water level drive the invasion of Vochysia divergens in Pantanal grasslands. Applied Vegetation Science, vol. 7, pp. 103-110.

FEENER JUNIOR, D.H., ORR, M.R., WACKFORD, K.M., LONGO, J.M., BENSON, W.W. and GILBERT, L.E., 2008. Geographic variation in resource dominance discovery in Brazilian ant communities. Ecology, vol. 89, no. 7, pp. 1824-1836. http:// dx.doi.org/10.1890/07-0659.1. PMid:18705370.

GIRARD, P., FANTIN-CRUZ, I., OLIVEIRA, S., LOVERDE, M. and HAMILTON, S.K., 2010. Small-scale spatial variation of inundation dynamics in a floodplain of the Pantanal (Brazil). Hydrobiologia, vol. 638, no. 1, pp. 223-233. http://dx.doi. org/10.1007/s10750-009-0046-9.

HALFFTER, G. and MATTHEWS, E.G., 1966. The natural history of dung beetles of the subfamily Scarabaeinae (Coleoptera: Scarabaeidae). Folia Entomológica Mexicana, vol. 121, no. 4, pp. 1-312.

HALFFTER, G., 1991. Historical and ecological factors determining the geographical distribution of beetles (Coleoptera: Scarabaeidae: Scarabaeinae). Folia Entomológica Mexicana, vol. 82, pp. 195-238.

HALFFTER, G., FAVILA, M.E. and HALFFTER, V., 1992. A comparative study of the structure of the scarab guild in Mexican tropical rain forests and derived ecosystems. Folia Entomológica Mexicana, vol. 84, pp. 131-156.

HAMILTON, S.K., SIPPEL, S.J. and MELACK, J.M., 1996. Inundation patterns in the Pantanal wetland of South America determined from passive microwave remote sensing. Archiv für Hydrobiologie, vol. 137, pp. 1-23.
HAMILTON, S.K., SIPPEL, S.J., CALHEIROS, D.F. and MELACK, J.M., 1997. An anoxic event and other biogeochemical effects of the Pantanal wetland on the Paraguay River. Limnology and Oceanography, vol. 42, no. 2, pp. 257-272. http://dx.doi. org/10.4319/lo.1997.42.2.0257.

HECKMAN, C.W., 1998. The seasonal succession of biotic communities in wetlands of the tropical wet-and-dry climatic zone: V. Aquatic invertebrate communities in the Pantanal of Mato Grosso, Brazil. International Review of Hydrobiology, vol. 18, no. 3, pp. 31-63. http://dx.doi.org/10.1002/iroh.19980830105.

JUNK, W.J. and CUNHA, C.N., 2005. Pantanal: a large South American wetland at a crossroads. Ecological Engineering, vol. 24, no. 4, pp. 391-401. http://dx.doi.org/10.1016/j.ecoleng.2004.11.012.

JUNK, W.J. and WELCOMME, R.L., 1990. Floodplains. In: B.C. PATTEN, ed. Wetlands and shallow continental water bodies. The Hague: SPB Academic. 772 p.

JUNK, W.J., 1997. General aspects of floodplain ecology with special reference to Amazonian floodplains. In: W.J. JUNK, ed. The Central Amazon floodplain. Berlin: Springer, pp. 3-20. Ecological Studies.

JUNK, W.J., BAYLEY, P.B. and SPARKS, R.E., 1989. The flood pulse concept in river-floodplain systems. Canadian Journal of Fishers and Aquatic, vol. 106, pp. 110-127.

JUNK, W.J., CUNHA, C.N., WANTZEN, K.M., PETERMANN, P., STRÜSSMANN, C., MARQUES, M.I. and ADIS, J., 2006. Biodiversity and its conservation in the Pantanal of Mato Grosso, Brazil. Aquatic Sciences, vol. 68, no. 3, pp. 278-309. http://dx.doi. org/10.1007/s00027-006-0851-4.

JUNK, W.J., WANTZEN, K.M., NUNES-DA-CUNHA, C. and SILVA, C.J., 2011. Ecology, biodiversity and sustainable management of the Pantanal: a synthesis. In: W.J. JUNK, C.J. SILVA, C.N. CUNHA and K.M. WANTZEN, eds. The Pantanal: ecology, biodiversity and sustainable management of a large neotropical seasonal wetland. Sofia-Moscow: Pensoft, pp. 835-857.

LEGENDRE, P. and LEGENDRE, L., 1998. Numerical ecology. 2nd ed. Amsterdam: Elsevier. 853 p.

LI, R.Y. and GELWICK, F., 2005. The relationship of environmental factors to spatial and temporal variation of fish assemblages in a floodplain river in Texas, USA. Ecology Freshwater Fish, vol. 14 , no. 4 , pp. 319-330. http://dx.doi.org/10.1111/j.16000633.2005.00106.x.

MAGNUSSON, W.E., LIMA, A.P., LUIZÃO, R., LUIZÃO, F., COSTA, F.R.C., CASTILHO, C.V. and KINUPP, V.F., 2005. RAPELD: uma modificação do método de Gentry para inventários de biodiversidade em sítios para pesquisa ecológica de longa duração. Biota Neotropica, vol. 2, pp. 1-6.

MILHOMEM, M.S., MELLO, F.Z.V. and DINIZ, I.R., 2003. Técnicas de coleta de besouros copronecrófagos no Cerrado. Pesquisa Agropecuaria Brasileira, vol. 38, no. 11, pp. 1249-1256. http://dx.doi.org/10.1590/S0100-204X2003001100001.

NADJA, G.M., 2013. Efeitos da inundação sobre o solo e vegetação com dominância de Vochysia divergens Pohl. (Vochysiaceae) no Pantanal mato-grossense. Cuiabá: Programa de Pós-graduação em Física Ambiental, Instituto de Física, Universidade Federal de Mato Grosso, 61 p.

NAVARRETE, D. and HALFFTER, G., 2008. Dung beetles (Coleoptera: Scarabaeidae: Scarabaeinae) diversity in continuous forest, forest fragments and cattle pastures in a landscape of Chiapas, Mexico: the effects of anthropogenic changes. Biodiversity 
and Conservation, vol. 17, no. 12, pp. 2869-2898. http://dx.doi. org/10.1007/s10531-008-9402-8.

POFF, N.L., ALLAN, J.D., BAIN, M.B., KARR, J.R., PRESTEGAARD, K.L., RICHTER, B.D., SPARKS, R.E. and STROMBERG, J.C., 1997. The natural flow regime: a paradigm for river conservation and restoration. Bioscience, vol. 47, no. 11, pp. 769-784. http://dx.doi.org/10.2307/1313099.

POTT, V.J., CERVI, A.C., BUENO, N.C. and POTT, A., 1996. Dinâmica da vegetação aquática de uma lagoa permanente da Fazenda Nhumirim, Pantanal da Nhecolândia, MS. In: Anais do II Simpósio sobre recursos naturais e sócio-econômicos do Pantanal, 1996, Corumbá, MS. Cuiabá: CPAP-EMBRAPA/ UFMS, pp. 227-235.

R DEVELOPMENT CORE TEAM, 2008 [viewed 10 March 2009]. $R$ : a language and environment for statistical computing [online]. Vienna: R Foundation for Statistical Computing. Available from: http://www.R-project.org

SCHWARTZ, M.W., BRIGHAM, C.A., HOEKSEMA, J.D., LYONS, K.G., MILLS, M.H. and VAN MANTGEM, P.J., 2000. Linking biodiversity to ecosystem function: implications for conservation ecology. Oecologia, vol. 122, no. 3, pp. 297-305. http://dx.doi.org/10.1007/s004420050035.
SETÄLÄ, H., BERG, M.P. and JONES, T.H., 2005. Trophic structure and functional redundancy in soil communities. In: R.D. BARDGETT, D.W. HOPKINS and M.D. USHER, eds. Biological diversity and function in soils. Cambridge: Cambridge University Press, pp. 236-249.

SILVA, M.P., MAURO, R.A., MOURÃO, G. and COUTINHO, M.E., 2000. Distribuição e quantificação de classes de vegetação do Pantanal através de levantamento aéreo. Revista Brasileira de Botanica, vol. 23, no. 2, pp. 143-152. http://dx.doi.org/10.1590/ S0100-84042000000200004.

TSUBO, M., FUKAI, S., BASNAYAKE, J., TUONG, T.P., BOUMAN, B. and HARNPICHITVITAYA, H., 2005. Estimating percolation and lateral water flow on sloping in rainfed lowland rice ecosystem. Plant Production Science, vol. 8, no. 3, pp. 354357. http://dx.doi.org/10.1626/pps.8.354.

TSUBO, M., FUKAI, S., BASNAYAKE, J., TUONG, T.P., BOUMAN, B. and HARNPICHITVITAYA, H., 2007. Effects of soil clay content on water balance and productivity in rainfed lowland rice ecosystem in northeast Thailand. Plant Production Science, vol. 10, no. 2, pp. 232-241. http://dx.doi.org/10.1626/ pps.10.232.

WILKINSON, L., 2004. Systat, Version 11.0. San José: Software Inc. 